\title{
HUBUNGAN ANTARA PENGETAHUAN KELUARGA DAN POLA KONSUMSI PANGAN TERHADAP KEJADIAN GONDOK PADA ANAK USIA SEKOLAH DI SDN PANDANSARI 02 KECAMATAN PONCOKUSUMO KABUPATEN MALANG
}

\author{
Devita Ari Pratiwi ${ }^{1}$, Gita Sekar Prihanti², Febri Endra Budi Setyawan ${ }^{3}$
}

Fakultas Kedokteran Universitas Muhammadiyah Malang, J1. Bendungan Sutami No. 188A, Kota Malang, 65145, Indonesia 0341-551149

\begin{abstract}
ABSTRAK
HUBUNGAN ANTARA PENGETAHUAN KELUARGA DAN POLA KONSUMSI PANHUBUNGAN ANTARA PENGETAHUAN KELUARGA DAN POLA KONSUMSI PANGAN TERHADAP KEJADIAN GONDOK PADA ANAK USIA SEKOLAH DI SDN PANDANSARI 02 KECAMATAN PONCOKUSUMO KABUPATEN MALANG. Latar Belakang: Gondok saat ini masih menjadi masalah di Indonesia. Di Jawa Timur tahun 2003 terdapat 33\% kecamatan kategori endemik. Kabupaten Malang pada tahun 2009 terdapat 24,00\% termasuk daerah endemik. Faktor - faktor yang dapat mempengaruhi pembesaran kelenjar gondok yaitu tingkat pengetahuan keluarga, konsumsi makanan sumber yodium, konsumsi bahan goitrogenik, dan penggunaan garam beryodium. Tujuan: Mengetahui hubungan pengetahuan keluarga dan pola konsumsi pangan dengan kejadian gondok pada anak usia sekolah di SDN Pandansari 2 kecamatan poncokusumo kabupaten Malang. Metode penelitian: Penelitian ini merupakan Non Eksperimental dengan desain case-control study (retrospekstif). Sampel berjumlah 36 anak. Data diperoleh dari pemeriksaan palpasi, wawancara kuesioner kepada ibu dan metode food recall dan food frequency untuk anak. Penelitian ini menggunakan analisis multivariat dengan uji statistik Regresi Logistik. Hasil: Pada kelompok gondok, ibu berpengetahuan kurang sebanyak $16 \mathrm{ibu}(88.9 \%)$, sumber yodium rendah sebanyak 16 (88.9\%), 13 anak (72,2\%) mengonsumsi goitrogen tinggi dan 27 anak, 10 anak (55.6\%) menggunakan garam yang memenuhi syarat. Pada kelompok non-gondok, ibu berpengetahuan kurang sebanyak 6 ibu (33.3\%), konsumsi makanan sumber yodium rendah 5 anak (27.8\%), 4 anak $(22.2 \%)$ mengonsumsi bahan goitrogen tinggi, dan 13 anak $(72.2 \%)$ menggunakan garam yang memenuhi syarat. Hasil Uji regresi logistik menunjukkan 3 variabel yang mempengaruhi, pengetahuan $(\mathrm{p}=0.045)$, makanan sumber yodium $(p=0.009)$, bahan goitrogenik $(p=0.029)$, sedangkan variabel garam $(p=0.244)$ tidak termasuk faktor yang mempengaruhi kejadian gondok. Dengan $R$ square $=0.716$. Kesimpulan: Ada hubungan yang signifikan antara pengetahuan keluarga dan pola konsumsi sumber yodium dan goitrogenik terhadap kejadian gondok pada anak usia sekolah di SDN Pandansari 2. Konsumsi garam tidak mempengaruhi kejadian gondok pada anak usia sekolah di SDN Pandansari 2 kecamatan Poncokusumo kabupaten Malang.
\end{abstract}

\begin{abstract}
THE CORRELATION BETWEEN FAMILY KNOWLEDGE AND FOOD CONSUMPTION PATTERN WITH GOITRE OCCURENCE IN SCHOOL AGE AT PANDANSARI 2 ELEMENTARY SCHOOL PONCOKUSUMO DISTRICT MALANG. Background: Goitre still becomes a problem in Indonesia. In east Java 2003 there are 33\% district in endemic, in Malang 2009 there are 24\% in endemic area. The factors which can influence the goitre is family knowledge, food with iodine consumption, goitrogenic food consumption, and the usage of salt with iodine. Objective: To know the correlation between family knowledge and food consumption pattern with goitre occurence in school age at Pandansari 2 elementary school Poncokusumo district Malang. Research Methode: This research is non-experimental research with casecontrol study (retrospekstif) design. The sample amount of 36 children. The data to get carried out thyroid palpation, interviewed the mother, and food recall and food frequency methode for the children. This research use multivariate analysis with Regression Logistic test. Results:In goitre group, mother with less knowledge are 16 mothers (88.9\%), 16 (88.9\%) in low consumption of food with iodine, 13 children (72,2\%) in bigh consumption of food goitrogenic, 10 children (55.6\%) use a salt with iodine. In non-goitre group, mother with less knowledge are 6 mothers (33.3\%), 5 children (27.8\%) in low consumption of food with iodine, 4 children $(22.2 \%)$ in bigh consumption of food goitrogenic, and 13 children (72.2\%) use a salt with iodine. The results of Regression Logistic test show that 3 variables which can influence are: knowledge $(p=0.045)$, food with iodine $(p=0.009)$, goitrogenic food $(p=0.029)$, while salt $(p=0.244)$ is not a factor which can influence the goitre occurrence, with $\mathrm{R}$ square $=0.716$. Conclutions: There are significant correlation between family knowledge and food consumption pattern of iodine and goitrogenic sources with goitre occurence in school age at Pandansari 2 elementary school. And the usage of salt is not significantly influence the goitre occurrence in school age at Pandansari 2 elementary school.
\end{abstract}

Key Word:Knowledge, Food with Iodine Consumption, Goitrogenic Sources, Salt with Iodine, Goitre. 


\section{PENDAHULUAN}

GAKY (Gangguan Akibat Kekurangan Yodium) masih menjadi masalah kesehatan di negara-negara berkembang khususnya Indonesia. Tahun 1998 menemukan $33 \%$ kecamatan di Indonesia masuk kategori endemik, 21\% endemik ringan, 5\% endemik sedang, dan 7\% endemik berat. Prevalensi GAKY pada anak SD secara nasional pada tahun 1990 yaitu sebesar 27,7\%, kemudian turun menjadi 9,3\% pada tahun 1998. Namun pada tahun 2003 kembali meningkat menjadi 11,1\% (Soeharyo, 2003). Prevalensi Total Goiter Rate (TGR) di kabupaten Malang sendiri pada tahun 1998 sampai dengan 2003 mengalami kenaikan dari 22,7\% menjadi 24,00\% (Depkes Jatim, 2009). Pada tahun 2011 Badan Penanggulangan dan Pengembangan Gangguan Akibat Kurang Yodium (BP2GAKY) melakukan skrining pada sejumlah anak SD di kecamatan Poncokusumo. Berdasarkan hasil skrining dari 6 Desa yang terpilih yaitu Desa Dawuhan, Desa Lesti, Desa Gubugklakah, Desa Jambesari, Desa Pandansari, dan Desa Pabrikan diketahui hasil Total Goiter Rate (TGR) tertinggi di Desa Pandansari. Rata - rata nilai Urinary Iodine Excreation (UIE) di desa pandansari berada pada tingkat kekurangan yodium ringan yaitu 93,42 $\mu \mathrm{g} / \mathrm{L}$ (normal : $100-199 \mu \mathrm{g} / \mathrm{L}$ ) dengan nilai minimal $28 \mu \mathrm{g} / \mathrm{L}$ dan nilai maksimal $272 \mu \mathrm{g} / \mathrm{L}$.

Kenaikan persentase penggunaan garam beryodium pada rumah tangga dengan kadar iodium cukup (30 - 80 ppm) belum begitu berarti yaitu 25\% pada tahun 1982 menjadi $65 \%$ pada tahun 1998 , 65\% pada tahun 2002, dan 73\% pada tahun 2003 (Depkes RI, 2004). Tetapi pada tahun 2010 keluarga yang menggunakan garam beryodium naik menjadi $78,71 \%$, padahal target pemakaian harus memenuhi target sejumlah 90\% (Dinkes Kabupaten Malang, 2009). Kemungkinan hal ini disebabkan karena adanya produksi garam yang tidak beryodium atau dengan kadar yodium $<30$ ppm, dan sikap konsumen yang kurang kritis dan peduli terhadap produk garam konsumsi beryodium. Dampak dari GAKY tidak hanya pada pembesaran kelenjar gondok tetapi yang lebih penting adalah terhambatnya perkembangan kecerdasan otak pada janin dan anak, serta pengurangan IQ poin pada orang dewasa. Setiap penderita gondok mengalami defisit 5 IQ poin, setiap penderita keratin mengalami defisit 10 IQ poin, dan bayi lahir di daerah resiko GAKY akan mengalami defisit IQ 10 poin (Rusnelly, 2006). Dasar dari kekurangan gizi mikro maupun gizi makro dipengaruhi oleh pola konsumsi yang kurang baik. Kurangnya unsur yodium yang disebabkan karena kurangnya yodium dalam makanan maupun air minum serta unsur goitrogen merupakan penyebab dari pembesaran kelenjar gondok (Susiana, 2011). Hasil komoditas unggulan di kecamatan Poncokusumo produksi kubis (kol) berada pada peringkat kedua yaitu 21000 ton/tahun serta ubi kayu (singkong) 4500 ton/tahun (Pemkab Malang, 2013). Kubis dan ubi kayu (singkong) merupakan goitrogen alami yang paling penting (Saidin, 2009). Banyak faktor yang dapat mempengaruhi kestabilan yodium dalam garam.

Berdasarkan penelitian yang dilakukan I Komang Gunung pada tahun 2005 bahwa 25\% kandungan yodium hilang pada proses pemasakan yaitu tergantung dari bahan dan cara memasak. Susiana juga meneliti pada tahun 2011 bahwa semakin tinggi kadar air saat penyimpanan, maka semakin tinggi kadar yodium yang terlepas.

Keterkaitan tingkat pengetahuan dengan kasus GAKY dapat dijelaskan berdasarkan hasil penelitian Gunanti dkk (2004) tentang faktor yang berhubungan dengan ketersediaan garam beryodium di tingkat rumah tangga menyimpulkan bahwa tingkat pengetahuan responden tentang garam beryodium masih kurang. Sikap responden terhadap ketersediaan garam beryodium dirumah tangga sebagian besar mendukung, namun pada umumnya pedagang masih menyediakan garam non yodium di tingkat pasar, hal ini berdampak pada rendahnya ketersediaan garam beryodium di tingkat rumah tangga. Demikian juga dengan pola konsumsi pangan anak SD dengan kasus GAKY , berdasarkan penelitian Kartono (2006) tentang indikator Total Goiter Rate (TGR) Anak Sekolah Sebagai Dasar Kebijakan Program GAKY di Indonesia disimpulkan bahwa terdapat hubungan pola konsumsi pangan terhadap status GAKY anak SD, dimana sebagian besar anak (55,10\%) berada pada kisaran umur 11 - 12 tahun, dengan rata - rata umur 10,86 tahun. Berdasarkan jenis kelamin 36,7\% lakilaki dan 63,3\% perempuan yang menderita GAKY.

Berdasarkan uraian di atas penelitian ini bertujuan untuk mengetahui bagaimana hubungan antara pengetahuan dan pola konsumsi pangan keluarga terhadap kejadian gondok pada anak usia sekolah di SDN Pandansari 02 Kecamatan Poncokusumo Kabupaten Malang.

\section{METODE}

\section{Desain Penelitian}

Penelitian ini merupakan penelitian observasional analitik dengan menggunakan case control. Grade 0 sebagai kontrol dan grade 1 dan grade 2 sebagai kasus.

\section{Tempat dan Waktu Penelitian}

Penelitian dilakukan di SDN Pandansari 2 pada bulan April 2014.

\section{Populasi dan Sampel}

Populasi dari penelitian ini adalah semua siswa - siswi SDN Pandansari 2 kelas 4, 5, dan 6 dengan umur $10-12$ tahun dan semua Ibu dari siswa - siswi SDN Pandansari 2 kelas 4, 5, dan 6 yang berumur $10-12$ tahun. Sedangkan sampel penelitian adalah siswa-siswi dan ibu dari siswasiswi yang anaknya telah memenuhi kriteri inklusi dan eksklusi dengan menggunakan teknik pengambilan sampel Total Sampling.

Kriteria inklusi meliputi: bersedia mengikuti penelitian dengan mengisi form pernyataan, anak SD dengan kisaran umur 10 - 12 tahun, anak SD yang telah dipalpasi oleh dokter dan mengalami pembesaran kelenjar tiroid, ibu dari siswa SD yang sudah dipalpasi oleh dokter dan mengalami pembesaran kelenjar tiroid, anak SD yang tinggal bersama orang tua/keluarga, dan bila ditemukan anak SD dengan ibu yang sama keduanya dipilih sebagai responden. Sedangkan kriteria eksklusi adalah Anak SD yang menderita Penyakit Kronis (penyakit graves, autoimun). 


\section{Alat dan Bahan}

Alat dan bahan yang digunakan meliputi: Kuisioner (Form Food Recall $2 \times 24$ jam \& Form Food Frequency), Iodine test dengan Reagen YMR (Yodium Main Reagent), Daftar Komposisi Bahan Makanan (DKBM), Daftar Angka Kecukupan Mineral (AKM), dan Daftar Ukuran Rumah Tangga (URT) dibantu menggunakan Food Model.

\section{Analisis Data}

Setelah dilakukan pengisian kuisioner, langkah berikutnya adalah melakukan pengolahan dan analisa data. Pengolahan dan analisis data diperuntukan untuk melihat besarnya pengaruh variable independen dengan dependen, maka digunakan analisis multivariat dengan uji regresi logistic.

\section{HASIL DAN PEMBAHASAN}

\section{Deskripsi Karakteristik Responden}

Penelitian ini menggunakan metode analitik observasional dengan pendekatan case control untuk menilai kejadian gondok pada anak usia sekolah. Pengambilan data menggunakan data primer melalui hasil pemeriksaan palpasi dan wawancara menggunakan kuesioner, food frequency, dan food recall. Tujuan penelitian ini adalah untuk menilai hubungan antara pengetahuan keluarga dan pola konsumsi pangan terhadap kejadian gondok pada anak usia sekolah. Penelitian ini dilakukan di SDN Pandansari 2 pada tanggal 28 Mei, 3 Juni, \& 5 Juni 2014, dengan jumlah sampel sebanyak 36 anak yang terdiri dari 18 anak sebagai kelompok Gondok dan 18 anak sebagai kelompok Non-gondok. Kelompok Gondok merupakan kelompok anak-anak yang telah didiagnosis gondok oleh dokter dari puskesmas. Kelompok non-gondok merupakan kelompok anak-anak yang tidak sakit gondok.

Tabel 1. Karakteristik Sampel Penelitian

Gondok Non-gondok

\begin{tabular}{lllll}
\hline & $\mathrm{N}$ & $\%$ & $\mathrm{~N}$ & $\%$ \\
\hline Jenis Kelamin & 4 & 22.2 & 11 & 61.1 \\
Laki-laki & 14 & 77.8 & 7 & 38.9 \\
Perempuan & 18 & 100 & 18 & 100 \\
Total & & 38.9 & 8 & 44.4 \\
Umur & 7 & 27.8 & 3 & 16.7 \\
10 tahun & 5 & 33.3 & 7 & 38.9 \\
11 tahun & 6 & 100 & 18 & 100 \\
12 tahun & 18 & & & \\
Total & & 83.3 & 2 & 11.1 \\
Pengetahuan & 15 & 16.7 & 16 & 88.9 \\
Kurang & 3 & 100 & 18 & 100 \\
Baik & 18 & &
\end{tabular}

\section{Karakteristik}

Berdasarkan tabel di atas, karakteristik sampel penelitian menurut jenis kelamin diketahui bahwa jumlah siswa yang paling banyak menderita gondok pada jenis kelamin perempuan sebanyak 14 siswa (77.8\%) sedangkan untuk kelompok non-gondok paling banyak pada jenis kelamin laki-laki yaitu 11 siswa (61.1\%). Karakteristik sampel penelitian. umur sampel penelitian dibagi dalam 3 kelompok. yaitu umur 10 tahun, 11 tahun, dan umur 12 tahun. Hal ini berdasarkan pembagian umur menurut penelitian sebelumnya. Berdasarkan tabel 5.1 tersebut di atas dapat diketahui bahwa baik kelompok gondok maupun kelompok nongondok memiliki jumlah siswa yang paling banyak menderita gondok ada pada umur 10 tahun yaitu kelompok gondok 7 siswa $(38.9 \%)$ dan kelompok nongondok 8 (44.4\%).
Pengetahuan keluarga memiliki kategori pengetahuan baik ada pada kelompok non-gondok sejumlah $16 \mathrm{ibu}$ $(88.9 \%)$. Sedangkan untuk katori pengetahuan kurang paling banyak berada pada kelompok gondok sejumlah $15 \mathrm{ibu}$ $(83.3 \%)$.

\section{Analisis Data \\ Hubungan Antara Pengetahuan Keluarga dengan Kejadian Gondok}

Tingkat pengetahuan keluarga dilakukan dengan metode wawancara kuesioner. Masing - masing poin pertanyaan akan dianalisis. Hasil dari analisis tiap pertanyaan di tunjukkan pada tabel 2. Hasil dari tabel 2 akan menunjukkan pengetahuan mana yang berkemungkinan mempengaruhi dari kurangnya pengetahuan dari suatu keluarga. Berdasarkan 
tabel. $17 \mathrm{ibu}(94.4 \%)$ kelompok gondok mengetahui definisi gondok, $16 \mathrm{ibu}(88.8 \%)$ kelompok gondok mengetahui penyebab gondok, 2 ibu (11.1\%) kelompok gondok mengetahui makanan yang menimbulkan gondok, $8 \mathrm{ibu}$ (44.4\%) kelompok gondok mengetahui cara mencegah gondok, $6 \mathrm{ibu}(33.3 \%)$ kelompok gondok mengetahui pengertian yodium, 5 ibu $(26.8 \%)$ kelompok gondok mengetahui asal sumber yodium, $4 \mathrm{ibu}(22.2 \%)$ kelompok gondok mengetahui akibat kekurangan yodium, 2 ibu $(11.2 \%)$ kelompok gondok mengetahui hasil dari yodine test, 3 ibu (16.7\%) kelompok gondok mengetahui kapan memberikan garam pada masakan, 3 ibu (16.3\%) kelompok gondok mengetahui cara menyimpan garam yang baik, 3 ibu (16.7\%) kelompok gondok mengetahui cara pemerintah mengatasi gondok, $14 \mathrm{ibu}(77.7 \%)$ kelompok gondok dan $15 \mathrm{ibu}(83.3 \%)$ kelompok non-gondok yang membeli garam di dekat rumah, serta $16 \mathrm{ibu}(88.8 \%)$ kelompok gondok dan $17 \mathrm{ibu}$ (94.4\%) kelompok non-gondok menggunaan garam halus.

Tabel 2. Distribusi Responden Berdasarkan Pengetahuan Ibu dari Siswa SDN Pandansari 2.

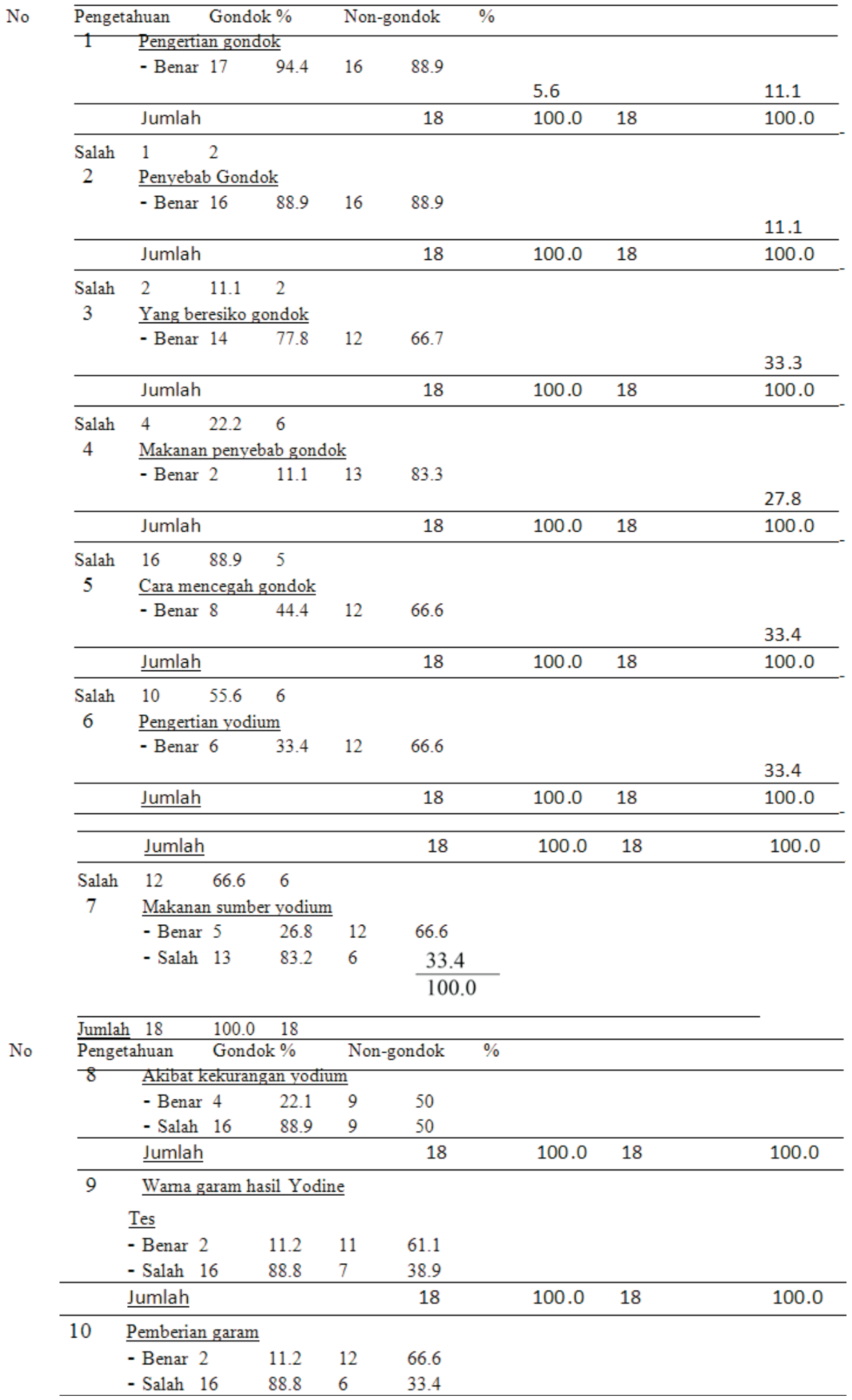




\begin{tabular}{|c|c|c|c|c|c|c|c|c|}
\hline & $\underline{\text { Jumlah }}$ & & & 18 & & 100.0 & 18 & 100.0 \\
\hline \multirow[t]{4}{*}{11} & \multicolumn{8}{|c|}{ Penyimpanan garam } \\
\hline & - Benar 3 & $\overline{16.7}$ & 11 & \multicolumn{5}{|l|}{61.1} \\
\hline & - Salah 15 & 83.3 & 7 & \multicolumn{5}{|l|}{38.9} \\
\hline & \multicolumn{3}{|l|}{ Jumlah } & \multicolumn{2}{|l|}{18} & 100.0 & 18 & 100.0 \\
\hline \multirow[t]{3}{*}{12} & \multicolumn{8}{|c|}{ Cara pemerintahmengurangi Gondok } \\
\hline & - Salah 15 & 83.3 & 9 & \multicolumn{5}{|c|}{50} \\
\hline & \multicolumn{3}{|l|}{ Jumlah } & \multicolumn{2}{|l|}{18} & 100.0 & 18 & 100.0 \\
\hline \multirow[t]{3}{*}{13} & \multicolumn{8}{|c|}{ Tempat pembelian garam } \\
\hline & \multicolumn{2}{|c|}{ - Di warung dekat rumah } & 14 & 77.7 & 15 & \multicolumn{2}{|l|}{83.2} & \\
\hline & \multicolumn{2}{|l|}{ Jumlah } & & \multicolumn{3}{|l|}{18} & 18 & 100.0 \\
\hline \multirow[t]{6}{*}{14} & \multicolumn{2}{|c|}{ Bentuk_garam } & yang & \multirow{2}{*}{\multicolumn{2}{|c|}{0}} & & & \\
\hline & \multicolumn{2}{|c|}{ digunakan - } & & & & 0 & 0 & 0 \\
\hline & \multicolumn{2}{|c|}{ Garam grasak } & & \multicolumn{2}{|l|}{2} & 11.2 & 1 & 5.6 \\
\hline & \multirow{2}{*}{\multicolumn{2}{|c|}{$\begin{array}{l}\text { - Garam Bata } \\
\text { - Garam Halus }\end{array}$}} & & \multicolumn{2}{|l|}{16} & 88.8 & 17 & 94.4 \\
\hline & & & & & & & \\
\hline & \multicolumn{2}{|l|}{ Jumlah } & & \multicolumn{2}{|l|}{18} & 100.0 & 18 & 100.0 \\
\hline & \multirow{2}{*}{\multicolumn{3}{|c|}{2.3316 .8 - Di beri tetangga 0}} & \multirow{2}{*}{\multicolumn{3}{|c|}{00}} & & \\
\hline & & & & & & & & \\
\hline
\end{tabular}

Untuk mengetahui hubungan antara pengetahuan keluarga dengan kejadian gondok digunakan uji analisis Chi - square yang hasilnya ditunjukkan pada tabel 3. Berdasarkan tabel 5.3 menunjukkan bahwa keluarga/ibu dengan pengetahuan kurang lebih banyak pada kelompok gondok yaitu sebesar 15 ibu (33.3\%) dan 3 ibu (16.7\%) memiliki pengetahuan baik. Sedangkan keluarga/ibu dengan pengetahuan baik lebih banyak pada siswa kelompok nongondok yaitu sebesar 12 ibu (66.7\%)dan 6 ibu (33.3\%) tergolong pengetahuan kurang.
Hasil tabulasi silang pada hubungan antara pengetahuan keluarga dengan kejadian gondok pada usia sekolah didapatkan nilai Chi - square hitung sebesar 9.257 dengan signifikansi sebesar 0.003 ( $p<0.005)$. Hal ini menunjukkan bahwa terdapat hubungan yang signifikan antara pengetahuan keluarga dengan kejadian gondok pada anak usia sekolah. Dengan nilai Odd ratio 0.100. nilai Odd ratio ini memiliki tingkat kepercayaan 95\% dengan nilai batas bawah0.021 dan batas atas 0.486 . Penelitian ini memiliki probabilitas sebesar $9.09 \%$. nilai ini menunjukkan bahwa anak dengan ibu dengan pengetahuan baik akan beresiko terkena gondok sebesar $9.09 \%$.

Tabel 3. Tabel Analisis Antara Pengetahuan dengan Kejadian Gondok

\begin{tabular}{|c|c|c|c|c|c|c|c|c|c|c|}
\hline & & & & & \multicolumn{4}{|c|}{ Gondok } & \multirow{3}{*}{\multicolumn{2}{|c|}{$\begin{array}{c}\text { Hasil } \\
\text { Analisis }\end{array}$}} \\
\hline & & & & & \multicolumn{2}{|c|}{ Gondok } & \multicolumn{2}{|c|}{ Non-gondok } & & \\
\hline & & & & & $\mathrm{N}$ & $\%$ & $\mathrm{~N}$ & $\%$ & & \\
\hline \multirow[t]{2}{*}{ Pengetah } & huan & Baik & 3 & 16.7 & 12 & 66.7 & & & & \\
\hline & & & & & & Kurang 15 & 83.3 & 6 & 33.3 & $\begin{array}{r}p=0.003 \\
x \quad 2=9.257\end{array}$ \\
\hline Total & 18 & 100.0 & 18 & 100.0 & & & & & & \\
\hline
\end{tabular}


Hubungan antara Pola Konsumsi Makanan sumber Yodium dengan Kejadian Gondok

Tabel 4. Distribusi Anak SD Berdasarkan Konsumsi Sumber Yodium

\begin{tabular}{|c|c|c|c|c|}
\hline \multirow{2}{*}{$\begin{array}{l}\text { No. } \\
1\end{array}$} & \multirow{2}{*}{$\begin{array}{l}\text { Bahan Makanan \& } \\
\text { Frekuensi } \\
\text { Ikan Laut }\end{array}$} & Gondok (\%) & \multicolumn{2}{|c|}{ Non - Gondok (\%) } \\
\hline & & & & \\
\hline & $3 x /$ hari & & & \\
\hline & $2 \mathrm{x} /$ hari & & 50 & \\
\hline & 1x/hari & & 27.8 & \\
\hline & $3-5 x /$ minggu & & 22.2 & \\
\hline & $<3 x /$ minggu & & & \\
\hline & $1-3 x /$ bulan (jarang) & & & \\
\hline & $\begin{array}{l}\text { Tidak di konsumsi dalam } \\
1 \text { tahun }\end{array}$ & 16.7 & & \\
\hline \multirow[t]{8}{*}{2} & Udang & & & \\
\hline & $3 x /$ hari & \multirow[b]{7}{*}{11.1} & & \\
\hline & $2 \mathrm{x} /$ hari & & & \\
\hline & 1x/hari & & & \\
\hline & $3-5 x /$ minggu & & & \\
\hline & $<3 \mathrm{x} / \mathrm{minggu}$ & & & \\
\hline & $1-3 x /$ bulan (jarang) & & 44.4 & \\
\hline & $\begin{array}{l}\text { Tidak di konsumsi dalam } \\
1 \text { tahun }\end{array}$ & & 27.8 & \\
\hline \multirow[t]{8}{*}{$\overline{3}$} & Kerang & & & \\
\hline & $3 \mathrm{x} /$ hari & & & \\
\hline & $2 \mathrm{x} / \mathrm{hari}$ & & & \\
\hline & $1 \mathrm{x} /$ hari & & & \\
\hline & $3-5 x / \operatorname{ming} g$ & & & \\
\hline & $<\hat{\mathrm{x}} / \operatorname{ming} \mathrm{gr}$ & & & \\
\hline & $1-\hat{3} /$ bulan (jaxang) & & & \\
\hline & $\begin{array}{l}\text { Tidak di konsumi dalam } \\
1 \text { tahun }\end{array}$ & & & \\
\hline \multirow[t]{8}{*}{4} & Ikan asin. & & & \\
\hline & $3 \mathrm{x} /$ hari & & & \\
\hline & $2 \mathrm{x} /$ hari & & 55.6 & \\
\hline & $1 \mathrm{~s} /$ hari & & 16.7 & \\
\hline & $3-5 x / \operatorname{ming} g$ & & 22.2 & \\
\hline & $<3 \mathrm{x} / \operatorname{ming} 4$ & 22.2 & 5.6 & \\
\hline & $1-3 \mathrm{x} /$ bulan (jarang) & 72.2 & & \\
\hline & $\begin{array}{l}\text { Tidat di kensumsi dalam } \\
1 \text { tahun }\end{array}$ & 5.6 & & \\
\hline \multirow[t]{8}{*}{5} & Ikan teri & & & \\
\hline & $\hat{3 x} /$ hati & & & \\
\hline & $2 \mathrm{x} /$ hari & & & \\
\hline & $1 \mathrm{x} /$ hari & & & \\
\hline & $3-5 x / \operatorname{ming} g y$ & & & 44.4 \\
\hline & $<\hat{\mathrm{x}} / \min \mathrm{gch}$ & 27.8 & & 33.4 \\
\hline & $1-\hat{3 x} /$ bulan (jarang) & 44.4 & & 11.1 \\
\hline & Tidal di konsumsi dalam 1 & 27.8 & & 11.1 \\
\hline
\end{tabular}




\begin{tabular}{|c|c|c|c|c|c|}
\hline 6 & Tixam & & & & \\
\hline & $\hat{3 x} /$ hari & & & & \\
\hline & $2 \mathrm{x} /$ hari & & & & \\
\hline & $1 \mathrm{x} /$ hari & & & & \\
\hline & $3-5 x / \operatorname{ming} g y$ & & & & \\
\hline & $<3 \mathrm{x} / \operatorname{ming} 4$ & & & & \\
\hline & $1-3 x /$ bulan $(j a r a n g)$ & & & & \\
\hline & Tidak di konsumsi dalam & & & & \\
\hline 7 & Bayam & & & & \\
\hline & $\hat{3 x} /$ harj & & & & 16.7 \\
\hline & $2 \mathrm{x} /$ hari & & & & 33.3 \\
\hline & $1 \mathrm{x} /$ hari & & & & 5.6 \\
\hline & $3-5 x / \min g g y$ & & 88.9 & & 44.4 \\
\hline & $<3 \mathrm{x} / \min g \mathrm{~g} y$ & & 11.1 & & \\
\hline & $1-\hat{x} /$ bulan (jarang) & & & & \\
\hline & $\begin{array}{l}\text { Tidak di konsum } \\
\text { dalam } 1 \text { tahun }\end{array}$ & & & & \\
\hline 8 & Susu. & & & & \\
\hline & $\hat{3 x} /$ hari & & & & \\
\hline & $2 \mathrm{x} /$ hari & & & & \\
\hline & $1 \mathrm{x} /$ hari & & & 55.6 & \\
\hline & $3-5 x / \operatorname{ming} g y$ & 38.9 & & 27.8 & \\
\hline & $<3 \mathrm{x} / \operatorname{ming} g$ & 22.2 & & 16.7 & \\
\hline & $1-3 x /$ bulan (jarang $)$ & 27.8 & & & \\
\hline & $\begin{array}{l}\text { Tidak di konsumsi dalam } \\
1 \text { tahun }\end{array}$ & 11.1 & & & \\
\hline
\end{tabular}

\begin{tabular}{|c|c|c|c|}
\hline$\overline{9}$ & Telur ayam & & \\
\hline & $3 \mathrm{x} / \mathrm{harj}$ & & \\
\hline & $2 \mathrm{x} / \mathrm{hagx}$ & & \\
\hline & $1 \mathrm{x} / \mathrm{hari}$ & & 66.7 \\
\hline & $3-5 x / \operatorname{ming} g$ & 38.9 & 16.7 \\
\hline & $<3 \mathrm{~s} / \operatorname{ming} \mathrm{g}$ & 22.2 & 16.7 \\
\hline & $1-3 \mathrm{x} /$ bulan (jarang) & 27.8 & \\
\hline & Tidak di konsumsi dalam 1 tahun & 11.1 & \\
\hline
\end{tabular}

\begin{tabular}{|c|c|c|c|}
\hline \multirow[t]{7}{*}{10} & \multicolumn{3}{|l|}{ Daging sapi } \\
\hline & \multicolumn{3}{|l|}{$\hat{3 x} /$ hari } \\
\hline & \multicolumn{3}{|l|}{$2 \mathrm{~s} / \mathrm{hari}$} \\
\hline & \multicolumn{3}{|l|}{$3-5 x / \operatorname{ming} g y$} \\
\hline & $<3 \mathrm{x} / \min \mathrm{g} g \mathrm{y}$ & & 22.2 \\
\hline & $1-\hat{3} / \mathrm{bulan}$ (jarang) & 16.7 & 44.4 \\
\hline & Tidal di konsumsi dalam 1 tahun & 55.6 & $3 \hat{3.4}$ \\
\hline 11 & \multicolumn{3}{|l|}{ Kentang } \\
\hline & \multicolumn{3}{|l|}{$3 \mathrm{x} /$ hari } \\
\hline & \multicolumn{3}{|l|}{$2 \mathrm{x} /$ hari } \\
\hline & \multicolumn{3}{|l|}{$1 x /$ harj } \\
\hline & $3-5 x / \operatorname{ming} g$ & & 50 \\
\hline & $<3 \mathrm{x} / \min \mathrm{g}_{\mathrm{a}} \mathrm{g}$ & 44.4 & 16.7 \\
\hline & $1-3 \mathrm{x} / \mathrm{kul}$ an (jarang) & 50 & 33.3 \\
\hline & Tidal di konsumsi dalam 1 thn & 5.6 & \\
\hline
\end{tabular}




\begin{tabular}{|c|c|c|}
\hline 12 & Rumput laut & \\
\hline & $3 \mathrm{x} /$ hari & \\
\hline & $2 \mathrm{x} /$ hari & \\
\hline & $1 \mathrm{x} /$ hari & \\
\hline & $3-5 x / \operatorname{ming} g y$ & \\
\hline & $<3 \mathrm{x} / \operatorname{ming} \mathrm{s}$ & 5.6 \\
\hline & $1-3 x /$ bulan (jarang) & 72.2 \\
\hline & Tidak di konsumsi dalam 1 thn & 22.2 \\
\hline
\end{tabular}

makanan sumber yodium untuk ikan laut sejumlah 15 anak (83.3\%) kelompok Gondok tergolong pada 1-3x/bulan dan 9 anak (50\%) kelompok non-gondok tergolong pada $2 \mathrm{x} /$ hari. udang 2 anak (11.1\%) kelompok gondok tergolong tidak dikonsumsi dalam 1 tahun dan 8 anak (44.4\%) kelompok non-gondok tergolong $<3 \mathrm{x} /$ minggu, pada konsumsi kerang baik kelompok gondok maupun kelompok non-gondok tidak ada yang pernah mengonsumsi sebelumnya, ikan asin 13 anak (72.2\%) kelompok gondok tergolong 1-3x/bulan dan 10 anak (55.6\%) kelompok non-gondok tergolong $2 \mathrm{x} /$ hari, ikan teri 8 anak (44.4\%) kelompok gondok dan kelompok nongondok tergolong 1-3x/bulan, pada konsumsi tiram baik kelompok gondok maupun kelompok non-gondok tidak ada yang pernah mengonsumsi sebelumnya, bayam 16 anak $(88.9 \%)$ kelompok gondok tergolong $3-5 \mathrm{x} /$ minggu dan 8 anak (44.4\%) kelompok nongondok tergolong $3-5 \mathrm{x} /$

minggu, susu 7 anak (38.9\%) kelompok gondok tergolong $3-5 \mathrm{x} /$ minggu dan 10 anak (5.6\%) kelompok non-gondok tergolong $1 \mathrm{x} /$ hari, telur ayam 10 anak (55.6\%) kelompok gondok tergolong $<3 \mathrm{x} /$ minggu dan 12 anak (66.7\%) kelompok non-gondok tergolong $1 \mathrm{x} /$ hari, daging sapi 10 anak (55.6\%) kelompok gondok tergolong tidak pernah mengonsumsi dalam satu tahun dan 8 anak $(33.3 \%)$ kelompok non-gondok tergolong $1-3 \mathrm{x} /$ bulan, kentang 9 anak $(50 \%)$ kelompok gondok tergolong $1-3 \mathrm{x} /$ bulan dan 13 anak (72.2\%) kelompok non-gondok tergolong 1-3x/ bulan. rumput laut pada kelompok gondok belum pernah memakan rumput laut dan 13 anak (72.2\%) kelompok nongondok tergolong 1-3x/bulan.

Untuk mengetahui hubungan antara makanan sumber yodium dengan kejadian gondok digunakan uji analisis Fisher seperti pada tabel 5 .

Tabel 5. Hasil Analisis antara Makanan

\section{Sumber Yodium dengan Kejadian Gondok}

\begin{tabular}{ccccc}
\hline \multicolumn{3}{c}{ Gondok } & & Hasil \\
\cline { 1 - 3 } Gondok & & Non -gondok & & Analisis \\
\cline { 1 - 4 } $\mathrm{N}$ & $\%$ & $\mathrm{~N}$ & $\%$ &
\end{tabular}

$\begin{array}{lllllll}\text { Makanan Tinggi } & 2 & 11.1 & 13 & 72.2 & \\ \text { sumber } & \text { Rendah } & \mathrm{p}= & 0.000 & & & \\ \text { yodium } & 16 & 88.9 & 5 & 27.8 & \text { X } \quad 2=11.429 \\ \text { Total } & 18 & 100.0 & 18 & 100.0 & & \end{array}$

Tabel 5 menunjukkan bahwa siswa yang tidak mengalami gondok mengonsumsi makanan sumber yodium kategori tinggi sebanyak 13 siswa (72.2\%) dan 5 siswa $(27.8 \%)$ lainnya mengonsumsi makanan sumber yodium kategori rendah. Sedangkan pada siswa yang mengalami gondok mengonsumsi makanan sumber yodium kategori tinggi sebanyak 2 siswa $(11.1 \%$ ) dan 16 siswa $(88.9 \%)$ lainnya mengonsumsi makanan sumber yodium kategori rendah.

\section{Pembahasan}

Berdasarkan analisis data diketahui bahwa pengetahuan ibu kelompok gondok lebih banyak pada kategori kurang daripada kelompok non-gondok, pola konsumsi sumber yodium lebih banyak pada kelompok non-gondok daripada kelompok gondok, untuk konsumsi makanan goitrogen lebih banyak dikonsumsi kelompok gondok daripada kelompok non-gondok, sedangkan untuk garam beryodium baik dari kelompok gondok maupun kelompok non-gondok sudah banyak yang mengonsumsi garam halus beryodium. Dari ke empat variabel bebas, ada 3 variabel yang dapat mempengaruhi kejadian gondok yaitu pengetahuan keluarga, makanan sumber yodium, dan bahan goitrogen. Sedangkan garam tidak mempengaruhi kejadian gondok pada anak usia sekolah.

Gondok masih belum memiliki penyebab yang pasti, tetapi banyak faktor pencetus yang dapat mempengaruhi uptake yodium oleh kelenjar tiroid yaitu letak geografi suatu daerah, faktor lingkungan (bahan goitrogenik alami dan sintetis) (Saidin, 2009), tingkat pengetahuan ibu (Rosidi A, 2008), dan genetik (Djokomoeljanto R, 2007). Pada penelitian ini hanya 3 yang di teliti yaitu pengetahuan keluarga, faktor lingkungan/pola konsumsi sumber yodium dan goitrogen.

\section{Gambaran Tempat Penelitian}

SD Negeri Pandansari 2 terletak di desa Pandansari kecamatan Poncokusumo Kabupaten Malang. Desa 
Pandansari terletak di ketinggian 1200 - $1400 \mathrm{Mdpl}$ dan terletak di kaki gunung semeru (Pemerintah Kabupaten Malang, 2013). Daerah pegunungan memiliki kandungan yodium tanah dan air yang sedikit, hal ini disebabkan karena air hujan yang meresap kedalam tanah membawa unsur mineral dalam air dan tanah mengalir ke arah laut. (Panjaitan $\mathrm{R}$, 2008). Hasil komoditas unggulan di kecamatan Poncokusumo produksi kubis (kol) berada pada peringkat kedua yaitu 21000 ton/tahun serta ubi kayu (singkong) 4500 ton/tahun (Pemerintah Kabupaten Malang, 2013). Kubis dan ubi kayu (singkong) merupakan goitrogen alami yang paling penting (Saidin, 2009)

Berdasarkan hasil survei BP2GAKY di kecamatan Poncokusumo rata-rata nilai UIE anak SD Negeri Pandansari sebesar $93,52 \%$. Nilai ini termasuk dalam gondok endemik sedang. Dari masing - masing jumlah sampel SD di Kecamatan Poncokusumo, SD Negeri Pandansari 2 memiliki jumlah sampel gondok paling banyak yaitu sebesar 122 siswa. Berdasarkan hasil penelitian ditemukan bahwa sebagian besar kelompok non - gondok memiliki pengetahuan yang baik sejumlah $12 \mathrm{ibu}(66,7 \%)$ dan sebagian besar kelompok gondok memiliki pengetahuan yang kurang sejumlah 15 ibu $(33.3 \%)$.

Pengetahuan adalah apa yang diketahui tentang sesuatu yang di dapat baik secara formal maupun informal. Pengetahuan yang dimiliki sangat penting untuk terbentuknya sikap dan tindakan seseorang. Hal ini juga berlaku dalam pemenuhan gizi bagi setiap orang. Seseorang yang didasari dengan pengetahuan gizi yang baik akan memperhatikan keadaan gizi setiap makanan yang dikonsumsi. Pengetahuan gizi sangat diperukan dalam upaya pemilihan makanan yang akan dikonsumsi, dengan tujuan agar makanan tersebut memberikan gizi yang sesuai dengan kebutuhan oleh tubuh atau sering disebut dengan gizi seimbang (Siregar E.R, 2009).

Pemenuhan nutrisi yodium di dalam tubuh dipenuhi melalui bahan makanan yang dikonsumsi. Seseorang dengan pengetahuan yang baik mengenai bahan sumber yodium akan memiliki pemenuhan nutrisi yodium lebih optimal dari pada yang memiliki pengetahuan kurang. Hal ini disebabkan karena pengetahuan yang baik mengenai nutrisi yodium, goitrogenik, maupun gondok akan menjadi suatu perubahan perilaku lalu akan menjadi suatu sikap kemudian menjadi tindakan yang nyata. Jika sebuah keluarga tidak mengetahui pentingnya unsur yodium, efek zat goitrogen bagi tubuh maka akan terjadi ketidak seimbangan nutrisi. Bila hal ini berulang terus - menerus makan akan menjadi sebuah kebiasaan dan akhirnya akan membentuk gaya hidup(Kurniasari A, 2012).

\section{Pola Konsumsi Pangan}

Hasil penelitian ini menunjukkan dari 18 siswa kelompok gondok sebagian besar ada pada kategori konsumsi sumber yodium rendah yaitu 16 siswa (88.9\%) dan dari 18 siswa kelompok non-gondok sebagian besar anak ada pada kategori konsumsi sumber yodium tinggi yaitu 13 siswa $(72.2 \%)$. Sedangkan pada konsumsi bahan goitrogenik, sebagian besar kelompok gondok ada pada kategori tinggi sejumlah 13 anak $(72.2 \%)$ dan sebagian besar kelompok non-gondok ada pada kategori rendah sejumlah 14 anak
(77.8\%). Pola konsumsi pangan merupakan gambaran mengenai jumlah, jenis, dan frekuensi bahan makanan yang dikonsumsi seseorang sehari - hari dan merupakan ciri khas pada suatu kelompok masyarakat tertentu. Konsumsi pangan merupakan faktor utama untuk memenuhi kebutuhan gizi seseorang (Murray, Rodwell, 2009). Tingkat konsumsi ditentukan oleh kualitas dan kuantitas makanan yang dimakan. Kualitas menunjukkan kandungan gizi yang terkandung dalam makanan, dalam hal ini yodium dan kandungan yodium dalam garam yang dikonsumsi, kuantitas menunjukkan jumlah masing - masing zat gizi terhadap kebutuhan tubuh akan yodium. (Sediaoetama, 2006).

\section{Kejadian Gondok pada Anak Usia Sekolah}

Penelitian yang telah dilakukan mengambil sampel sebanyak 36 siswa-siswi SD dengan 18 siswa kelompok gondok dan 18 siswa kelompok non-gondok. Kelompok gondok merupakan kelompok anak yang mengalami gondok. Data gondok pada anak diperoleh dari pemeriksaan fisik, palpasi, oleh dokter dan petugas puskesmas. Gondok merupakan suatu pembengkakkan pada leher oleh karena pembesaran kelenjar tiroid akibat kelainan glandula tiroid, dapat berupa gangguan fungsi atau perubahan susunan kelenjar dan morfologinya.(Price, 2006).

Gondok mudah terjadi di daerah pegunungan, hal ini disebabkan karena kandungan yodium dalam air dan tanah berkurang sebagai akibat dari air hujan yang yang meresap ke tanah lalu membawa unsur yodium di dalam tanah mengalir ke arah laut (Panjaitan R, 2008). Penentuan status GAKY dapat dilakukan dengan menggunakan metode palpasi, ekskresi yodium urin, dan TSH neonatal (Djokomoeljanto, 2006). Sebagaimana diketahun anak SD masih dalam fase pertumbuhan dan perkembangan fisik, proses pematangan organ reproduksi dan merupakan fase sensitif terhadap kekurangan kekurangan unsur yodium. Dimana kebutuhan unsur yodium relative lebih besar, sehingga defisiensi yodium dalam fase ini mudah sekali menyebabkan pembesaran kelenjar tiroid, sebagai mekanisme kompensasi terhadap penurunan hormon tiroksin. Hormon tiroksin berperan pada metabolisme protein yang sangat penting bagi perkembangan sel otot dan tulang (Panjaitan, 2008).

\section{Hubungan Antara Pengetahuan dengan Gondok pada Anak Usia Sekolah}

Berdasarkan data yang diperoleh, dari 36 ibu responden yang terdiri dari 18 ibu kelompok gondok dan $18 \mathrm{ibu}$ kelompok non-gondok terdapat. Diketahui bahwa $15 \mathrm{ibu}$ (83.3\%) kelompok gondok yang memiliki pengetahuan kurang dan $12 \mathrm{ibu}(66.7 \%)$ kelompok non-gondok memiliki pengetahuan baik. Dari data kuesioner ditemukan ibu pada kelompok gondok masih memiliki pengetahuan yang kurang yaitu pada pertanyaan-pertanyaan mengenai makanan sumber yodium, cara mencegah gondok, pegertian yodium, makanan sumber yodium, hasil tes yodium, akibat kekurangan yodium, pemberian garam beryodium, penyimpanan garam, dan cara pemerintah mengurangi gondok. Dengan hasil regresi logistik didapatkan $\mathrm{p}=0.045(\mathrm{p}<0.05)$ nilai ini menunjukkan terdapat hubungan yang signifikan antara pengetahuan 
keluarga dengan kejadian gondok. Hasil ini menunjukkan semakin tinggi pengetahuan ibu, maka semakin kecil kemungkinan terkena gondok karena ibu dengan pengetahuan yang baik dapat memenuhi kebutuhan gizi, terutama yodium secara optimal (Kurniasari A, 2012). Nilai Odd ratio $=0,100$ hasil ini bermakna sebagai penghambat, maka pengetahuan yang baik dapat menghambat kejadian gondok, dengan kemungkinan kejadian sebesar 9,09\%. Hasil ini sejalan dengan penelitian cross secsional guananti dkk (2004) tingkat pengetahuan ibu berpengaruh terhadap status GAKY anak SD. Pengetahuan merupakan hasil dari tahu dan ini terjadi setelah orang melakukan penginderaan terhadap suatu objek tertentu, atau diperolehnya dari pengalaman. Secara umum pengetahuan dapat diperoleh dari berbagai bentuk objek seperti leaflet, buku, majalah, televisi, radio, dan media lainnya yang memberikan kontribusi ilmu tentang upaya pencegahan dan penanggulangan penyakit GAKY. (Notoatmodjo, 2003).

\section{Hubungan Antara Pola Konsumsi Sumber Yodium dengan Kejadian Gondok pada Anak Usia Sekolah}

Kadar yodium dalam bahan makanan bervariasi dan dipengaruhi oleh letak geografis, musim, dan cara memasak. Bahan makanan yodium memiliki kandungan yang berbeda - beda misalnya ikan laut memiliki kandungan yodum 83,2 $\mu \mathrm{g} / 100$ gram bahan, tahu - tempe 3,0 $\mu \mathrm{g} / 100$ gram bahan, susu 4,7 $\mu \mathrm{g} / 100$ gram bahan dan lain sebagainya. (Panjaitan, 2008). Dari olah data didapatkan sebagian besar kelompok gondok ada pada kategori konsumsi sumber yodium rendah yaitu 16 siswa $(88.9 \%$ ) dan sebagian besar anak kelompok non-gondok ada pada kategori konsumsi sumber yodium tinggi yaitu 13 siswa $(72.2 \%)$. Hasil uji statistik menunjukkan bahwa konsumsi sumber yodium berpengaruh terhadap kejadian gondok pada anak usia sekolah dengan nilai uji Regresi logistik 0,009 ( $\mathrm{p}<0,005)$. Hal ini menunjukkan bahwa terdapat hubungan yang signifikan antara makanan sumber yodium dengan kejadian gondok. Hasil ini menunjukkan bahwa konsumsi makanan dengan sumber yodium yang tinggi, maka kemungkinan terjadinya gondok semakin kecil. Nilai Odd ratio $=0,048$ bermakna sebagai penghambat, maka konsumsi sumber yodium yang tinggi dapat menghambat kejadian gondok, dengan kemungkinan kejadiannya sebesar $4.58 \%$. Hasil ini sejalan dengan penelitian Ritanto (2005) bahwa anak SD yang tidak mengonsumsi pangan sumber yodium, maka 68,2\% menderita GAKY.

Yodium merupakan mikronutrien esensial yang dibutuhkan oleh tubuh manusia untuk bahan pembuatan/ mensintesis hormon tiroid. Hormon tiroid ini selanjutnya akan berperan dalam proses metabolisme di dalam tubuh seperti pembentukan kalori, metabolisme karbohidrat, protein, kolesterol, proses pertumbuhan, perkembangan dan maturasi kerja saraf, konsumsi oksigen, dan metabilosme basal. (Murray G, Rodwell W, 2009).

\section{Hubungan Antara Makanan Goitrogenik dengan Kejadian Gondok pada Anak Usia Sekolah}

Dari penelitian ini didapatkan sebagian besar kelompok gondok ada pada kategori konsumsi bahan goitrogenik tinggi sejumlah 13 anak (72.2\%) dan sebagian besar kelompok non-gondok ada pada kategori konsumsi bahan goitrogenik rendah sejumlah 14 anak (77.8\%). Hasil uji logistik menunjukkan bahwa terdapat hubungan antara konsumsi bahan goitrogenik dengan kejadian gondok pada anak usia sekolah dengan nilai $\mathrm{p}=0,029(\mathrm{p}<0,005)$. Nilai ini menunjukkan bahwa terdapat hubungan yang signifikan antara bahan makanan goitrogenik dengan kejadian gondok pada anak usia sekolah. Maka semakin rendah konsumsi bahan goitrogenik, kemungkinan menderita gondok semakin kecil. Nilai Odd ratio $=9.100$ bermakna sebagai pemicu, maka konsumsi bahan goitrogen yang tinggi dapat memicu kejadian gondok, maka anak yang mengonsumsi bahan goitrogen 9 kali lebih besar kemungkinannya dapat terkena gondok, dengan kemungkinan kejadian sebesar 90\%. Hal ini disebabkan karena terdapat kompetisi antara yodida dan zat tiosinat dari bahan goitrogen (Ganong WF, 2003). Pada penelitian ini responden sering mengonsumsi makanan goitrogenik dengan jenis daun singkong 33,3\% 3x/hari, ketela rambat 5,6\% $3 \mathrm{x} /$ hari, rebung $11,1 \% 3 \mathrm{x} /$ hari, kubis $50 \% 3 x /$ hari, dan bawang $88,9 \%$. (Data Primer, 2014)

Goitrogenik adalah suatu zat yang menghambat uptake yodium oleh kelenjar tiroid. Keberadaan zat goitrogenik akan menjadi nyata jika terjadi kekurangan yodium (Kartono D, 2006) Makin tinggi tingkat kekurangan yodium yang dialami akan semakin banyak komplikasi atau kelainan yang ditimbulkan. Kelainan yang dimaksud seperti pembesaran kelenjar tiroid (kelenjar tiroid) dan berbagai stadium sampai timbulnya tuli dan gangguan mental akibat kreatinisme. GAKY ini umumnya lebih banyak terjadi di daerah pegunungan dimana makanan setempat yang berasal dari tanaman yang tumbuh pada kondisi tanah dengan kadar yodium rendah ( Thaha AR, Jafar N, 2002). Hasil penelitian Aritonang (2004) dari berbagai jenis bahan makanan yang dikonsumsi oleh pelajar berdasarkan makanan tinggi kandungan yodium dan bahan makanan mengandung zat goitrogenik, diketahui bahwa ikan laut segar sangat jarang sehingga intake yodium dari makanan laut sangat rendah. Keadaan ini juga diperberat dengan keadaan geografi dan topografi daerah yang berada di dataran tinggi di mana secara alami kandungan yodium pada lingkungan baik lingkungan air maupun lingkungan tanah sangat rendah. Hal ini juga dipengaruhi dengan seringnya msyarakat mengonsumsi makanan yang diduga mengandung zat goitrogenik seperti singkong, daun singkong, dan kol. Dari beberapa hasil penelitian pada kelinci percobaan diketahui bahwa famili kubis (kol) dapat menyebabkan pembesaran kelenjar tiroid setelah diberikan kepada kelinci selama 40 hari. Konsumsi jengkol dan asam juga relatif sering melalui jenis makanan daerah yaitu arsikyang banyak menggunakan asam, sedangkan jengkol dan asam juga diketahui mengandung zat goitrogenik. Zat goitrogenik dalam proses pembentukan hormon tiroid menghambat pengambilan yodium oleh kelenjar tiroid atau menghalangi pembentukan ikatan organik antara yodium dan tirosin untuk menjadi hormon tiroid. (Bahri S, 2003).

Hal ini menunjukkan bahwa pola konsumsi pangan pada pelajar SD tersebut kurang baik dalam arti jumlah dan kualitas makanan yang dikonsumsi relatif kurang. Bila dilihat salah satu dampak GAKY adalah menghambat pertumbuhan berdasarkan survei konsumsi pangan yang ditemukan konsumsinya ubi kayu yang mengandung 
goitrogenik setiap hari maka pertumbuhan pelajar tersebut relatif menjadi terhambat. Bahan makanan yang mengandung zat goitrogenik justru merupakan bahan makanan (sayursayuran) yang banyak tumbuh dan dibudidayakan di kecamatan poncokusumo, sehingga secara umum menjadi sayuran utama yang dikonsumsi. Untuk mengatasi kondisi tersebut diupayakan dalam penyediaan makanan keluarga mengurangi seminimal mungkin jenis sayuran yang mengandung zat goitrogenik.

Sesuai dengan penelitian Murdiana A, Saidin S (2006) tentang cara mengurangi kadar goitrogenik jenis tiosinat di daerah gondok endemik yaitu pundong Yogyakarta dan Srumbung Magelang. Rata-rata sianida bahan makanan mentah berkisar $2-38 \%$ dan bila di tumis sebesar 40 $70 \%$. Selain cara tersebut penurunan kadar sianida juga bisa dilakukan dengan fermentasi dan merendam.

Goitrogenik pada umumnya berperan sebagai penghambat transport aktif ion yodida $\left(\mathrm{I}^{-}\right)$ke dalam kelenjar tiroid sehingga menghambat fungsi tiroid. Salah satu jenis goitrogenik ini adalah golongan tiosinat (SCN), tiosinat akan berkompetisi dengan yodida ketika memasuki sel tiroid karena volume dan muatannya sama. Tiosinat masuk ke dalam darah dan membentuk ion-ion goitrogenik dan akan mengikat ion-ion yodium, akibatnya yodida yang akan digunakan untuk pembentukan hormon T1 dan T2 sebagai prekursor hormon T3 dan T4 berkurang sehingga pembentukan hormon T3 dan T4 akan menurun.

\section{Hubungan Penggunaan Garam Beryodium dengan Kejadian Gondok Pada Anak Usia Sekolah}

Secara umum garam merupakan suatu pangan sangat dibutuhkan dalam menyedapkan masakan, namun tidak semua garam memiliki kandungan yodium yang sesuai dengan standar (30-80 ppm). Hasil penelitian menunjukkan bahwa sebagian besar anak kelompok gondok memakai garam beryodium sejumlah 10 anak $(55.6 \%)$ dan sebagian besar anak kelompok non-gondok memakai garam beryodium sejumlah 13 anak (72.2\%). Uji Fisher menunjukkan nilai $p$ $=0,244(\mathrm{p}>0,005)$ artinya penggunaan garam beryodium tidak mempengaruhi kejadian gondok pada anak usia sekolah, walaupun pada realitanya masih terdapat kejadian gondok pada anak usia sekolah. Hal ini disebabkan karena penyimpanan garam dalam 1 tahun dapat menurunkan kadar yodium sebesar $20 \%$ dalam wadah tertutup pada kelembaban relatif $60 \%$ dan suhu $40^{\circ} \mathrm{C}$, yang seharusnya garam disimpan di suhu ruangan, tidak terkena sinar matahari dan panas perapian. (Nurrakhmawati, 2011).

Di negara-negara berkembang konsumsi yodium paling banyak diperoleh dari makanan yang berasal dari laut mengandung yodium tinggi. Oleh karena itu makanan seperti rumput laut, ikan, kepiting, udang, dan tanaman yang ada di dekat laut yang merupakan sumber yodium yang paling baik. Selaim itu konsumsi yodium juga dapat diperoleh dari garam yang telah di fortifikasi yodium dan air (Muhilal, 2005). Cara penambahan garam juga mempengaruhi kandungan yodium garam pada makanan. Berdasarkan penelitian Susiana SL (2011), cara menambahkan garam sebelum pemasakan menurunkan kadar yodium sebesar $68,2 \%$ sedangkan penambahan saat siap saji sebesar $19,46 \%$.
Terjadinya penurunan kadar yodium dan penguraiannya menjadi yodida memperlihatkan adanya pengaruh yang nyata dari suhu dan lama pemasakan, kandungan air, cara pengolahan, bumbu masak, dan tingkat keasaman terhadap kestabilan yodium. Proses perebusan, pengukusan, dan penumisan menunjukkan tingkat kerusakan kadar yodium yang berbeda serta proses pengolaham makanan yang lama cenderung menurunkan kadar yodium. Oleh karena itu pemberia garam lebih di sarankan pada saat setelah memasak, karena penurunan kadar yodium tidak sebesar saat diberikan saat memasak atau sebelum. Menggunakan garam dengan kandungan yodium tinggi (30-80 ppm) disarankan agar saat dimasak dengan bumbu dapur yang dapat menurunkan kadar garamdapat di atasi.

Penelitian lain milik Nadlir (2005) mengenai garam sebagai faktor resiko terjadinya kurang iodium tidak terbukti. Praktik penanganan dan perlakuan terhadap garam selama proses pemasakan menjadi sebab faktor tersebut tidak berhubungan. Hal ini sejalan dengan hasil penelitian Saksono N (2002) bahwa beberapa bumbu dapur dapat mengurangi kadar iodat garam. Cabai merupakan bumbu dapur yang paling besar mengakibatkan penurunan kadar iodat, lalu diikuti ketumbar dan merica. Ia juga menjelaskan bahwa konsentrasi awal iodat dapat mempengaruhi tingkat penurunan iodat. Untuk konsentrasi awal iodat 234,14 ppm, pada cabai ditemukan penurunan kadar iodat sebesar $100 \%$, sesangkan pada ketumbar dan merica masing-masing $56,32 \%$ dan $23,62 \%$. Hal ini disebabkan tereduksinya iodat oleh senyawa-senyawa pereduksi dalam bumbu dapur. Suasana asam dalam bumbu dapur dapat ditemtukan melalui $\mathrm{pH}$ bumbu dapur yang bersifat asam. Dari hasil penelitiannya menunjukkan cabai memiliki $\mathrm{pH}$ terendah yaitu 3,86 diikuti ketumbar dan merica masing-masing 5,67 dan 5,86. Oleh karena itu disarankan makan makanan sumber yodium seperti makanan dari laut, ikan tawar dll sebagai pemenuhan nutrisi yodium yang kurang.

\section{Hasil Uji Regresi}

Dari analisis uji regresi didapatkan nilai signifikansi pada masing - masing variabel yaitu pengetahuan orang tua $p=0.045(p<0.05)$, konsumsi sumber yodium $p=0.009$ $(p<0.05)$, konsumsi bahan goitrogenik $p=0.029(p<0.05)$ dengan nilai $\mathrm{R}$ square $=0.716(71.6 \%)$. Nilai ini menunjukkan bahwa pengetahuan yang rendah, konsumsi sumber yodium yang rendah, dan konsumsi goitrogen yang tinggi dapat meningkatkan kejadian gondpk pada anak usia sekolah di SD Negeri Pandansari 2 Kecamatan Poncokusumo Kabupaten Malang dengan besar kemungkina kejadian sebesar $71.6 \%$.

Berdasarkan beberapa hal yang dapat menimbulkan kejadian gondok, maka faktor-faktor yang dapat mempengaruhi dari penelitian ini adalah pengetahuan ibu, konsumsi makanan sumber yodium dan konsumsi bahan goitrogenik. Dimana bila 3 hal ini terjadi penurunan maka $71,6 \%$ akan terjadi GAKY dengan konsumsi sumber yodium sebagai faktor yang paling mempengaruhi kejadian gondok. Maka dari itu apabila anak yang mengonsumsi makanan sumber yodium tinggi meskipun pengetahuan ibunya kurang dan mngonsumsi bahan goitrogenik yang 
tinggi, anak tersebut dapat terhindar dari kejadian GAKY. Kelemahan penelitian ini adalah dalam menentukan gondok masih menggunakan metode yang sederhana yaitu palpasi. Dari 36 siswa, terdapat beberapa siswa yang tidak sepenuhnya dapat mengingat makanan pendamping seperti kerupuk, pilus, dan sejenisnya.

\section{DAFTAR PUSTAKA}

Almatsier S, 2007, Penuntun Diet, PT Gramedia Pustaka Utama, Jakarata

Almatsier S, 2009, Prinsip Dasar Ilmu Gizi, Gramedia Pustaka Utama, Jakarta

Arisman, 2004, Gizi Dalam Daur Kehidupan, Penerbit Buku Kedokteran (EGC), Jakarta

Aritonang E, Evinaria, 2004, Pola Konsumsi Pangan, Hubungannya dengan status Gizi dan Prestasi Belajar pada Anak SD di Daerah Endemik GAKY Desa Kuta Dame Kecamatan Kerajan Kabupaten Dairi propinsi Sumatra Utara, USU Digital Librabry, 118

Badan Penanggulangan dan Pengembangan Ganggguan Akibat Kurang Yodium, 2011, Data Skrining Gondok Pada Anak SD di Kecamatan Poncokusumo

Bahri S, 2003, Evaluasi Efek Goitrogenik Tiosinat pada Marmut, Balai Penelitian Penyakit Hewan, Vol.4, 9 12

Brandt, Eric, 2005, Thyroid Hormone Replacement Terapy, viewed 3 Desember 2013 http://www. druginformation.bc.ca/thyroid.htm

Briel VD, et al, 2000, Improved Lodine Status is Associated With Improved Mental Performance of Schoolchildren in Benin, American Society For Clinical Nutrition

Budiman, Riyanto A, 2013, Kapita Selekta Kuisioner Pengetahuan dan Sikap dalam Penelitian Kesehatan, Salemba Medika, Jakarta

Budiyanto MAK, 2004, Dasar - Dasar Ilmu Gizi, Universitas Muhammadiyah Malang, Malang

Dahro AM, dkk, 2004, Kestabilan Iodium Dalam Garam Pada Berbagai Tipe dan Resep Masakan, Jurnal Penelitian Gizi dan Makanan, Vol 19, 131 - 138

Departemen Kesehatan Jawa timur, 2009, Profil Kesehatan Provinsi Jawa Timur

Departemen Kesehatan RI, 2004, Rencana Aksi Nasional Kesinambungan Program Penanggulangan GAKY, RAN KPP GAKY, 1 - 17

Dinas Kesehatan Kabupaten Malang, 2009, Profil Kesehatan Kabupaten Malang Tahun 2009.

Dinas Profinsi Jawa timur, 2004, Panduan Penegakan Norma Sosial. Peningkatan Konsumsi Garam Beryodium, komite Nasional Garam Departemen Kesehatan, Jakarta

Djokomoeljanto R, 2007, Buku Ajar Ilmu Penyakit dalam FK UI, Pusat Penerbitan Ilmu Penyakit Dalam FKUI. Jakarta

Firdanisa R, 2011, HUbungan Konsumsi Sianida Makanan dengan Ekskresi Yodium Urin pada Anak SD di Daerah Endemik GAKY, S-2 Magister Gizi Masyarakat, Universitas Diponegoro, Semarang
Ganong WF, 2003, Buku Ajar Fisiologi Kedokteran Edisi 20, Penerbit Buku Kedokteran EGC, Jakarta

Gatie AL, 2006, Validasi Total Goiter Rate (TGR) Berdasar Palpasi Terhadap Ultrasonografi (USG) Tiroid Serta Kandungan Yodium Garam dan Air Di Kecamatan Sirampog Kabupaten Brebes,S-2 Magister Gizi Masyarakat, Universitas Diponegoro, Semarang

Greenspan F S, Baxter J D, 1994, Basic and Clinical Endocrinology $4^{\text {th }}, 1994$

Gunanti, 2004, Identifikasi Faktor yang Diduga Berhubungan dengan Kejadian Gondok pada Anak Sekolah Dasar di Daerah Dataran Rendah, Jurnal GAKY Indonesia. Vol 6. 17-30

Gunung IK, 2005, Kadar Yodium dalam Garam Beryodium yang dibutuhkan di Daerah Endemik, Majalah Kedokteran Udayana, Bali

Guyton, Hall, 2008, Buku Ajar Fisiologi Kedokteran, Penerbit Buku Kedokteran (EGC), Jakarta

Kartono D, 2006, Effectiveness of Iodine Deficiency Disorder (IDD) Control Program in Endemic Goiter Area in Five Province of Indonesia, University of Quensland Brisband

Kurniasari A, 2012, Hubungan Antara Pengetahuan dan Sikap Tentang GAKY dengan Kadar Yodium Garam Konsumsi Pada Keluarga Petani Garam, M.Kes Tesis, Universitas Diponegoro, Semarang

Linder M, 1992, Biokimia Nutrisi dan Metabolisme, Fakultas Kedokteran Universitas Indonesia, Jakarta

Moehji S, 1982, Ilmu Gizi Jilid 1, Bharatara Karya Aksara, Jakarta

Murray G, Rodwell W, 2009, Biokimia Harper edisi 27, Buku Kedokteran (EGC), Jakarta

Nadlir A, 2005, HUbungan Kadar Garam Iodium dan Pengetahuan Orang Tua dengan Kejadian Gondok Pada Anak Usia Sekolah Dasar/Madrasah Ibtidaiyah (Studi Kasus Di Kecamatn Kayen Kabupaten Pati), S1 Gizi, Universitas Padjajaran, Semarang

Notoatmodjo S, 2003, Pendidikan dan Perilaku Kesehatan, Rineka Cipta, Jakarta

Nurrakhmawati EY, 2012, Pola Konsumsi Pangan dan Kejadian Gondok di Daerah Gondok Endemis Gondok Berat, Amd.Gizi KTI, Politeknik Kesehatan, Malang

Panjaitan R, 2008, Pengaruh Karakteristik Ibu dan Pola Konsumsi Pangan Keluarga Terhadap Status GAKY anak SD di Kabupaten Dairi, M.Kes Tesis, Universitas Sumatra Utara, Sumatra

Pemerintah Kabupaten Malang, 2013, Profil Kecamatan Poncokusumo, viewed 23 Februari 2014 http:// poncokusumo. malangkab.go.id/?page_id $=5$

Price SA, 2006, Patofisiologi, Buku Kedokteran EGC, Jakarta

Putz R, Pabst R, 2006, Atlas Anatomi Manusia Sobotta jilid 1 edisi 22, Penerbit Buku Kedokteran EGC, Jakarta

Ritanto, 2005, Pengaruh Perilaku Ibu Terhadap Kekurangan Yodium Pada Anak SD di Kecamatan Selo Kabupaten Sleman, Jurnal GAKY Indonesia, vol.6, 47 - 50

Rosidi A, 2008, Hubungan Tingkat Pengetahuan Ibu Tentang Garam Beryodium dengan Ketersediaan Garam Beryodium pada TingkatRumah Tangga di Desa Krajan Kecamatan Tembaran Kabupaten Temanggung, Jurnal Kedokteran, Vol.1, 67- 79 
Rusnelly, 2006, Determinan Kejadian GAKY pada Anak Sekolah Dasar di Dataran Rendah dan Dataran Tinggi Kota Pagar Alam Profinsi Sumatra Selatan, M.Gizi Tesis, Universitas Diponegoro, Semarang

Saidin S, 2009, Hubungan Keadaan Geografi dan Lingkungan dengan Gangguan Akibat Kurang Yodium, Media Litbang Kesehatan, vol 19, 101 - 108 Saksono N, 2002, Analisis Iodat Dalam Bumbu Dapur Dengan Metode Iodometri dan X-Ray Fluoresence, Makara Teknologi, vol 6, 83 - 94

Santoso EB, dkk, 2008, Hubungan Antara Konsumsi Makanan Goitrogenik dan Status Iodium Pada Ibu Hamil Di Kecamatan Endemis Gangguan Akibat

Kekuarangan Iodium, Berita Kedokteran Masyarakat, vol. 33, $93-99$

Sartini DN, 2012, Hubungan Ekskresi Iodium Urin dan Ekskresi Tiosinat Urin Dengan Total Goiter Rate (Studi Pada Anak SD Kecamatan Bulakamba, Kabupaten Brebes Jawa Tengah), S1 kedokteran, Universitas Diponegoro, Semarang

Sediaoetama A, 2006, Ilmu Gizi, PT. Dian Rakyat, Jakarta Setiadi E, 1980, sifat goitrogenik singkong (Manihot Utilisima), Cermin Dunia Kedokteran, Jakarta

Silbernagl S, Lang F, 2007, Atlas \& Atlas Berwarna Patofisiologi, Buku Kedokteran EGC, Jakarta

Siregar E.R, 2009, Gambaran Pengetahuan Gizi, Pola Konsumsi Pangan dan

Status Gizi Pada Supir Angkot Rahayu Medan Ceria Trayek 104 di Kota Medan, M.Kes Tesis, Universitas Sumatra Utara, Medan

Soehardjo , 2003, Berbagai Cara Pendidikan Gizi, Bumi Aksara, Jakarta

Soeharyo H, dkk, 2003, Aspek Sosio-kultural pada Program Penanggulangan GAKY, Jurnal GAKY Indonesia, Vol 1, $41-48$

Suraji C, 2003, Faktor - Faktor yang Mempengaruhi Konsumsi Garam Beryodium di Rumah Tangga di Kecamatan Limbangan Kabupaten Kendal , M.Kes Tesis, Universitas Diponegoro, Semarang

Susiana SL, 2011, Faktor - faktor yang Berhubungan dengan Ekskresi Iodium Urin (EIU) pada Anak Sekolah Dasar di SDN 01 Sumberejo Kecamatan Randublatung Kabupaten Blora, S. Gizi Tugas Akhir, Universitas Diponegoro, Semarang

Thaha AR, Dachlan DM, Jafar N, 2002, Analisi Faktor Resiko Coastal Goiter, Jurnal GAKY Indonesia (Indonesian Journal of IDD), $\quad$ volume 1, 9-20 